Siune, K. \& Truetaschler, W. (red. (1992). Dynamics of Media Politics. Broadoast and Electronic Media in Westem Europe London: Sage.

Social Text nr. 25/26 The Phantom Public Sphere (1990). Stcvenson, N. (1995). Social Theory and Mass Communicaw hon. London: Sage.

Warner, M. (1990). The Letters and the Repwbiti. Publication and the Pubic Sphere in Eightenth-Century America. Cam. bridge: Harvard U.P.

- (1992). The Mass Public and the Mass Subject. In Calhoun (red) (1992).

Finn Frandsen er lektor ved Fransk Institut, Handelshøjskolen i Århus. Søren Kolstrup er lektor ved Institut for informations- og medievidenskab, Århus Universitet. 


\section{Audiovisuel formidling}

\section{Af Lennard Højbjerg}

I de senere år er formidling $i$ skrift, levende billeder og tale blevet en del af undervisningen og forskningen på landets universiteter. Men hoilken betydning har av-formidlingen i en akademisk sammenhong? Er det videnskabsbaseret undervisning? Eller blot anvendt film-og mediekundskab? Er det en (medie-) podagogisk disciplin? I denne artikel diskuterer Lennard Hojbjerg formidlingsdisciplinens videnskabelige status og iforlangelse heraf, giver han sit bud på, hvordan audiovisuel formidling og humanistisk teori kan indgå $i$ en hensigtsmassig syntese. Betragtningerne er dannet ud fra Lennard Hojbjergs egne erfaringer som underviser og forsker på Institut for Film- $\mathcal{G}^{\circ}$ Medievidenskab, Kobenhavns Universitet.

Det er en udbredt opfattelse, at undervisning og forskning i formidling centrerer sig om det praktiske aspekt af kommunikation med levende billeder. Og det betyder, at i common sense-opfattelsen af formidling er det forst og fremmest det praktiske, der afgrenser formidlingsbegrebet i forhold til den polære modsætning - det teoretiske. I de fleste formidlingsuddannelser på danske universiteter er det dog kommunikationen som sådan, der er formidlingsundervisningens emne Med kommunikation menes der, at en afsender med en rakke formidlingsmassige teknikker er i stand til at fremstille en tekst (i levende billeder, skrift, lyddias eller andet), som forstås af den tiltænkte modtager (gruppe). Unge eller andre videomaner, der fremstiller sig selv igennem mediet i en slags forsøg på at skabe en identitet, er udgranset i den kommunikationsopfattelse, som indgăr i formidlingsundervisningen på universiteterne.

Udgransningen af den kreative selvspejlingsproces viser os, at det er kommunikationsopfattelsen fra medieforskningen, der udger grundlaget for undervisningen. Fjernkommunikation - eller tekstuel kommunikation - med dens asymetriske akse; afsender-tekst vs tekst-modtager - spalter formidlingsundervisningen i to områder; ét, der arbejder med hvilke teknikker, teorier (herunder målgruppeanalyser) og formidlingsstrategier en afsender har til rådighed til fremstillingen af et tekstuelt budskab, og ét, som arbejder med, hvordan modtageren begriber det afsendte budskab med de kompetencer og praferencer, som udgor han/hendes forudsætninger.

Af de to perspektiver på formidling er det det forste, dét, der arbejder med hvilke formidlingsstrategier og tekstuelle teknikker, man făr en mălgruppe i tale med, som er prioriteret på nogle af uddannelsesstederne; mens andre uddannelsesinstitutioner kombinerer de to perspektiver. Man kan inddele de forskellige former for undervisning i av-formidling efter deres målbestemmelse:

a) av-formidling med det formål at udvikle kendskabet til mediernes kommunikative-tekstuelle funktionsmåde.

b) av-formidling med det formal at udvikle evnen til praktisk formidling.

c) av-formidling med det formål at udvikle kendskabet til formidlingen som teoretisk disciplin.

Der er tale om en lidt firkantet opdeling. Ingen praktisk formidling kommer f.eks. udenom visse teoretiske forudsatninger, og i de fleste tilfalde er der tale om en kombination af de forskellige typer af undervisning $i$ av-formidling.

Hvad karakteriserer forholdet mellem undervisning og forskning i de tre undervisningstyper? Det er tydeligt, at det er de forskellige hensigter (formål), der afger, hvordan de tre retninger »laner sig op ad den traditionelle videnskab, her forstäet bredt som teorier.

a) kommunikativ-tekstuel funktionsmåde 
Den forste undervisningsform har det formål at udvikle kendskabet til mediernes kommunikative-tekstuelle funktionmåde. En typisk case er f.eks. følgende: de studerende laser forskellige analyser af'TV-avisen og anden tv-fakta (f.eks. Larsen 1972, Prehn 1981, Højbjerg 1986 og Harms Larsens 1990). Teksterne diskuteres og indgår $\mathrm{i}$ en række analyser af konkrete tv-nyheder, hvorefter der stilles én eller flere praktiske opgaver i fakta-fremstilling på video tiltænkt f.eks. en landdækkende kanals nyhedsmagasin. De forskellige produktioner evalueres, og $\mathrm{i}$ evalueringen lagges der forst og fremmest vagt pă formidlingen - har de mulige (hypotetiske modtagere) forstået nyhedsfremstillingen på video? Og i tilfalde af, at de ikke har det - hvorfor ikke?

Formidlingsstrategieme analyseres - er den rigtige rakkefolge af informationer valgt? Er den mest hensigtsmassige vinkling benyttet? Hvad er normerne for den type af formidling? Overskrides normerne? osv. Man kan sige, at de praktiske produktioner cr en slags padagogisk omvej til en mere nuanceret og detaljeret forstaelse af isar kommunikative-tekstuelle forhold.

Denne type undervisning i formidling kan man med god ret kalde for den mediepedagogiske av-formidling. Gennem de praktiske ovelser făr man viden om detaljer, synsvinkler, fortalleforhold osv. i faktaformidling, som ingen teori, netop i kraft af den er teori, kan indeholde. Det kan til en vis grad sammenlignes med den măde, man lærer sprog på - forst når man taler sproget opdager man, hvor vanskeligt det er, og hvilke problemer, der skal loses for at kunne tale flydende og nogenlunde korrekt.

b) praktisk formidling

Den anden type af undervisning søger at udvikle evnen til audiovisuel formidling gennem praktiske øvelser. De studerende stilles en formidlingsopgave; overbevis folgende målgruppe om det rigtige i folgende budskab (f.eks. i form af et indslag i cn trafikoplysningskampagne, AIDs-kampagne, oplysning om skatteforhold, instruktionsvideoer af den ene eller anden art osv).

Efter undervisning i detaljerede målgruppeanalyser, slippes produktionsgrupperne fri. De superviseres undervejs, der diskuteres hvilken form, der skal vaelges, om den er brugt for, faktat, fiktion eller faktion - hvilken astetisk stil skal optagelserne foretages i osv. Grupperne producerer, og hvis ikke der tilfojes en egentlig receptionsanalyse af et udsnit af målgruppen, så fungerer lærer og plenum som en slags målgruppe, der evaluerer de frerdige produktioner - som regel i kraft af en formidlingsanalyse, der anskuer sammenhængen mellem kommunikationen til mălgruppen og vinklingen af den audiovisuelle tekst. Gennem gentagende øvelser med varierende formidlingsopgaver oparbejdes en viden og et praktisk kendskab til formidling. Resultatet er som regel en klar viden om, hvad man ikke skal gøre, năr man formidler, viden om, hvordan produktionsholdets indforståcde kommunikation ikke må bestemme den audiovisuelle tekst endelige form og en udviklet intuition for, hvordan formidlingsproblemer loses. Film- og medieteorier indgår i nogle tilfæelde og $i$ andre tilfalde ikke og $i$ ingen af tilfeldene som praskriptive forbilleder. De kan fungere som det begrebssat, man benytter til at diskutere de tekstuelle forhold (stil, komposition, narratologi, synsvinkler, modalitet etc.) under superviseringen og i evalueringsfasen.

\section{c) teoretisk formidling}

Undervisningen analyserer et eksempel på formidling, f.eks. en reklamekampagne, en oplysningskampagne mod AIDS, en trafikoplysningskampagne, en enkelt debatskabende faktaudsendelse i tv. Undersøgelser viser, at programmet - som forudberegnet af producenten - har en forholdsvis stor målgruppe, hvorefter der fokuseres pă, hvordan mălgruppen er sammensat. Der suppleres evt. med en receptionsanalyse af, hvordan et udsnit af målgruppen konkret har forstảet av-produktet. Formålet $\mathrm{er}$ at finde en sammenhang mellem av-produktionens formidlingsstrategi og den konstaterede forståelse/accept af budskabet hos målgruppen. Det forer til en formidlingsanalyse, der ser sammenhangen mellem av-produktionens vinkling af stoffet og målgruppens præferencer og kompetencer. Teorien har her en tilsvarende funktion som i de mere traditionelle tekstanalyser. Det er gennem analysen af av-produktets tekstuelle opbygning, at den samlede teksts vinkling kan beskrives. I modsatning til den traditionelle tekstanalyse er vagten dog her lagt på sammenhangen mellem den konkrete målgruppes reaktion og tekstens opbygning.

\section{Formidling og teori}

Teori-her forstået som audiovisuelle tekstteorier ${ }^{1}$ - indgår i de tre undervisningsformer pă forskellig 
måde. Formidlingsundervisningens 》brug « af tcori er måske ikke helt som den humanistiske videnskabstradition foreskriver det, bla. fordi et foreskrivende moment indgăr. Brugen af teori $\mathrm{i}$ formidlingsdisciplinerne er måske mere indlysende og selvfolgelig end egentlig velbegrundet. Teorien lases, fordi den siger noget om mediernes tekstuelle forhold; men det glemmes ofte, at tcorierne som regel er udviklet med henblik pä en analytisk forstăelse af teksten (f.eks. scmiotikken) og i mindre grad med det formål at skabe tekster. Det er ikke pă forhånd givet, at det cr to uforenelige perspektiver, men det cr heller ikke givet, at de to perspektiver cr sammenfaldende.

I det hele taget betragtes formidlingsdisciplinerne ikke som forskningsbaserede i samme grad som de traditionelle humanioradiscipliner med sarlig tanke på tekstanalysen. Det rejser selvfolgelig sporgsmålet om formidling er videnskab, anvendt videnskab cller noget helt tredje?

\section{Formidling og videnskab}

Tydeligt nok er formidling en del af forskningen, năr den f.eks. indgår som undersøgelsesperspektiv i konkrete receptionundersogelser. Her undersoges f.eks. TV-avisens nyheder og den tiltankte mălgruppes forstålse af dem (f.eks. Jensen 1994). Forståelsen og den manglende/specielle forståelse kan herefter forklares som udtryk for afsenderens brug af forskellige formidlingsstrategier eller tekstforhold, om man vil. Formidlingen har her status af det, der bliver undersøgt vha. en receptionsanalytisk projektramme og er derfor en del af den videnskabelige institution.

Mindre videnskabelig status har de forskningsprojekter, der beskriver, hvad god formidling er for noget, og hvilke formidlingsstrategier og tekstuelle trak en afsender kan tage i brug for at sikre sig en hensigtsmæssig kommunikation med sin tiltankte målgruppe. Om det er fordi, de praktiske anvis" ninger pä god kommunikation ikke falder inden. for den hermencutiske-tekstanaly tiske humanioratradition, eller om praktisk formidling falder for den klassiske positivistiske videnskabsopfattelse (distinktionen mellem praskriptivitet og deskriptivitet, som hhv. uvidenskabelig og videnskabelig) er vanskeligt at afgøre. Găr man ud over humanioras granser, er det imidlertid interessant at se, at her opstår samme distinktion mellem videnskabelighed (hard science) og uvidenskabelighed, når humaniora under ét sammenlignes med de natur- videnskabelige discipliner. For selvom der blandt humanioras mange ideografiske discipliner også findes nomotetiske (f.eks. lingvistikken), så betragtes de humanistiske discipliner ikke som hard science. Det er måske det, der er grunden til, at en del af medieforskningen laner sig op ad samfundsvidenskaben og dele af psykologien klaber til naturvidenskaben.

Imidlertid kan det i høj grad diskuteres, om den videnskabsopfattelse, der her inddeler og hierarkiserer de forskellige discipliner, ikke hviler på et spinkelt grundlag. Det er nemlig Soren Kjorups pointe $\mathrm{i}$ artiklen $»$ Semiotik og retorik « (1994). Kjorup diskuterer forskellen i videnskabsopfattelser i semiotikken og retorikken, hvor semiotikken har alle de klassiske videnskabelige egenskaber (den er nomotetisk og teoretisk), mens retorikken i forste omgang ma betegnes som en kunstart og derfor ideografisk og praktisk. Kjørups pointe er videre, at diskuteres grundlaget for videnskaben semiotik og grundlaget for retorikken, begynder den tidligere så sikkert formulerede adskillelse på grundlag af videnskabskriteriet at falde fra hinanden. Hvad, der definerer videnskabelighed (hvori der indgår begreber som sandhed, objektivitet og virkelighed) er i hoj grad et sporgsmăl om den sproglige formulering af det mønster, det paradigme (Kuhn 1962) den enkelte disciplin er en del af af; altså et sporgsmål om fremstilling, eller om man vil - formidling. Videnskabelige modeller, metaforer, udvikles i forlengelse af den videnskabelige tradition, man er en del af. De formuleres på baggrund af den forstâelseshorisont, som forskeren er en del af, og som prager de fremstillinger, han giver af sine resultater og teorier.

Retorikken barer dog også en erkendelsesteori i sig, havder Kjørup. Retorikken er beslagtet med logikken, men har sin force i viden om, hvordan man organiserer argumentcr i en tekst, når genstanden er ssandsynligheder (f.eks. tekstfortolkningens sargumenter ), mens logikken er den disciplin, der organiserer argumenterne i almengyldige sandheder. I områder af livet, hvor afgørelser ikke kan traffes pă et strikt grundlag: "...kommer så retorikken os til hjalp med dens påpegning af, at selv hvor vi ikke har et endeligt og sikkert fundament for erkendelsen, har vi altid et konkret, socialt og traditionsforankret udgangspunkt. \& (Kjorup 1994: 27)

De humanistiske videnskaber lever ikke op til de naturvidenskabelige forestillinger om rigtig videnskab (og skal ikke gøre det). Alligevel oprettes 
der indenfor humaniora samme hierarki som mellem humaniora og naturvidenskab. Her er formidling ikke ligeså videnskabelig, som den pertentligt udforte analyse af en tekst. Tilsyneladende hersker forestillingen om, at den, der analyserer, folger regler og analysemetoder, som i en eller anden forstand er sanktioneret af den videnskabelige institution, mens producenten/afsenderen af en tekst i sin kreative proces ikke følgcr regler og procedure, der er intersubjektivt kontrollerbarc ${ }^{2}$. Og selvom den tekstfortolkende hermeneutiske tradition i nogle sammenhænge hviler på nomotetiske tekstmodeller, hvis gyldighed ogsă kan drages i tvivl ${ }^{3}$, så indeholder den analyserende-fortolkende aktivitet altid et moment af subjektivitet. Hvordan argumenm teres der for, at teksten har de betydninger, den har? Hvordan fremstilles fortolkningen? Her kan kun argumenterne talle, men netop den type argumenter, der ligger uden for den formelle logiks rammer.

Det er m.a.o. ikke så enkelt at undgå den retoriske dimension i det videnskabelige arbejde indenfor den humanistiske tekstanalyserende institution. Løsningen er derfor også mere radikalt at reffektere den formidlingsmæssige dimension og inddrage retorikkens forstålelse af argumentation og metode i fremstillingen af feks. videnskabelige resultater.

Udover disse mere principielle overvejelser over de forskellige discipliners videnskabelige status kan man imidlertid sporge sig selv, om det ikke er muligt at indarbejde de nometetiske tekstmodeller i den ideografiske formidlingsdisciplin? Når det drejer sig om audiovisuelle tekster, er der udviklet en lang række teorier. Disse filmfortalleteorier beskriver, hvorledes filmens betydninger opstår og kades sammen til tekstuel mening. Der er ingen tvivl om, at sadanne teorier kan bruges i de ideografiske formidlingsdiscipliner men hyordan? Eksempler er allerede givet i det foregående, men kan tekstteorier, i hajere grad og mere intensivt, benyttes cnd i de navnte undervisningsformer? Det er jo heller ikkc nogen hemmelighed, at mange prakti. kere i film- og tv-branchen anser videnskabelig teori for uinteressant, abstrakt og uanvendelig i praktisk formidling. Her lever myten om enten håndverkerens spontanitet eller kunstmerens $\mathrm{ly}$ sende genialitet. Ligesom kunstnerens geniale ind.fald, skabes der i producentens hoved intuitivt ly. sende ideer om, hvordan teksten skal skrues sammen.

Det efterfolgende er et forsog på at fremsille en audiovisuel metode (Hojbjerg 1996), der i et vist omfang minimerer »den gale kreativitet《 $\mathrm{i}$ formidlingsprocessen ved at inddrage fortalle- og tekstteorier. Ved at opstille en procedure for, hvorledes man kan analyserc en stor del af den proces, der går forud for den planlagte produktionsproces af en tv-udsendelse, reduceres graden af tilfældighed og intuition og graden af wvidenskabelighed øges. Det fjerner ikke den kendsgerning, at der altid vil vare kreative momenter og intuition i produktionprocessen, som ikke kan videnskabeliggores. Samtidig skal der gøres opmarksom på, at det som presenteres er noget andet end de mmetoder«, der feks. fremstilles i TV-Sum-konceptet. Her beskrives »gode « og »effektive « tekstuelle strategier i kommunikationen (underforstået: brug dem!). Det, som fremstilles i det efterfolgende, er et analytisk-metodisk apparat, der - når det tages i anvendelse - kan give dem, som onsker at fremstille audiovisuelle tekster, en rakke muligheder at valge i mellem - om man f.eks. onsker at folge visse normer for kommunikation, eller onsker at bryde dem osv? Der foreskrives ikke den effektive eller den idcelle kommunikation, der anvises kun forskellige muligheder at vælge imellem.

\section{Den audiovisuelle metode}

Den audiovisuelle metode er tænkt som et analyseredskab i den pre-produktionelle fase. Ud over den praproduktionelle fase arbejdes der med selve produktionen og postproduktionen. I en undervisningssammenhang kan man forestille sig et forlob, hvor der er introduceret relcvante teorier/begreber. En formidlingsopgave skal loses i form af et videoprodukt. I den prxproduktionelle fase skal formidlingsgrupperne - ud fra et oplxg - skabe en idé, en synops/treatment og manus og drejebog. Det $\mathrm{cr}$ her, den audiovisuelle metode skal benyttes. Metoden indenholder en slags kogebogs-procedure med en rakke trin, der fordrer både film- og tv-historisk viden og film- og tv-analytisk viden.

Indledningsvis kan man kalde den audiovisuelle metode for den omvendte flim-og tw-analyse. I film- og tv-analysen analyseres et vark (film, tvudsendelse, kortfilm og lignende) gennem brugen af en rakke analytiske begreber eller modeller, om man vil. Forst rekonstrueres fortallingens forskellige plot-forhold, sat ind i et genrepcrspektiv med udblik til den historiske tradition varket også er placeret $\mathrm{i}$, så man kan beskrive fortallingens pointer på handlingsplanet. Herefter kan analysen 
fortsatte med naste trin - f.eks. en narratologisk analyse af hvilke personer og objekter, der flyttes rundt $\mathrm{i}$ universet og andrer udgangspunkt, forud. sætninger og vardier. Verdier og tematik fremstilles $i$ den tematologiske analyse, som er neste trin i analysen. Her er man så fremme ved selve filmens mening - i nogle analysetraditioner beskrevet som den fortolkende fase. Filmens/tv-udsendelsens tema-f.eks. menneskets ubodelige ensomhed - kan så enten relateres til varkeksterne faktorer - det er et billede af den tid, vi lever i, og som typisk tegner det kapitalistiske samfunds fremmedgørende livsformer (den socialhistoriske metode) - eller til instruktorens sarlige personlighed (den biografiske metode) eller blot fremlægges som varkets egen mening (f.eks nykritikken og/eller semiologien).

Den her foreslâede metode gor det omvendt. Der er allerede en idé, en mening, som man onsker at viderebringe til den tiltænkte målgruppe. Varkets mening er-placeret i et kommunikationsperspektiv - afsenderens (producentens/instruktorens/institutionens) intention - materialiseret $i$ det audiovisuelle produkt - som modtageren i bedste fald gennem oplevelsen af filmen eller tv-udsendelsen begriber. Herefter kan den mening, det budskab, som endnu ikke er materialiseret, underkastes en proces, hvor en lang rakke analytiske varktojer fra den humanistiske analysetradition kan hjolpe teksten på vej. Det er en systematisk måde at vare praktisk formidlende på. Den systematiske del indeholder en rakke trin bestående af forskellige analyseformer:

1) analyse af kommunikationssituationen

2) formidlingsanalysen

3) formidlingsastetikken - herunder fortalleforhold osv.

$\mathrm{På}$ hver enkelt trin $\mathrm{i}$ den systematiske procedure kan der anlagges et historisk perspektiv. Man kan "gå på tvaers« og f.eks. analysere udviklingen i de (f.eks.) tekstuclle normer, der benyttes i en bestemt periode - f.eks. faktagenrens brug af fiktionale fortælleformer i $1980^{\prime} \mathrm{crne}$. Også smagsnormer eller holdningsskift hos målgruppen kan analyseres, men også mere specifikke trak - f.eks. en bestemt tv-genres stilistiske udvikling i de sidste 30 år kan analysere. I det historiske perspektiv analyseres det normbillede, man som producent selv står i, og sættes i perspektiv af, hvordan tidligere fremstillingsnormer har varet og, hvordan man eventuelt kan forestille sig helt nye.

\section{Det systematiske perspektiv}

Indledningsvis begyndes med at fastlagge intentionen med den videoproduktion man nu skal i gang med, herefter defineres mălgruppen, og man kan på denne baggrund overveje, hvordan det audiovisuelle forlob skal opbygges, hvilken genre, der tam ges i anvendelse, og hvordan dramaturgi eller fakta-sagsfremstilling, i form af informationemes rekkefolge og synswinkler, opbygger indslaget. Endelig kan man afgranse hvilke stilistiske trek, den fardige produktion ikke skal benytte, hvilke der skal benyttes, om modalitelen ${ }^{4}$ skal vare neutral osv. Man har $m$, a.o. en række analyseredskaber til rảdighed: hhv. analyse af kommunikationssituationen, formidlingsanalyse og formidlingsastetik.

\section{Analyse af kommunikationssituationen}

Den simple kommunikationsmodel danner udgangspunkt for de kategorier, der indgår i den audiovisuelle metode. Dette er afbildet i model 1 . Modellen er en simpel (men til dette formál tilstrækkelig) fremstilling af tckstuel kommunikam tion, her med de audiovisuelle mediers tekster som det, der er i centrum.

$\mathrm{Vi}$ antager, at kommunikationsintentionen foreligger og skal nu - for overhovedet at kunne diskutere, hvilke fortalleformer, der skal benyttes

\section{Model 1}
Afsender $\Rightarrow$ (intention)
Budskab (genre, aestetik, fortalleformer)
Modtager/målgruppe (begriben - kompetence og præeference) 
i den genre, som produktet skal fremstilles i - forst definere målgruppen. Hvordan vil den givne målgruppe begribe det fremstillede - hvordan skal vi fremstille vores budskab og dermed vores intention - mening - for at målgruppen begriber det, og hvilke smagsformer (praferencer) og hvilke afkodningsmassige redskaber (audiovisuelt sproglige kompetencer og hverdagsviden har modtageren til rådighed?

Der er udarbejdet mange modeller for målgruppeanalyse, hvori blandt den mest nuancerede er den merkantilt prægede săkaldte segmentanalyse. Her inddeles efter livsholdninger, dagligdagens opbygning, arbejdsforhold, medievaner og meget andet - altså det vi meget bredt kalder kompetencer og præferencer i et hverdagslivs-perspektiv. Resultatet bliver, at man kan bestemme sin målgruppes smag, hverdag og livsvisioner helt ned i bitte små detaljer og herefter planlagge sit merkantile projekt (feks. en reklamekampagne) derefter.

\section{Formidlingsanalysen}

Både i tilfalde af mere specifikke og bredere målgrupper er en formidlingsanalyse ofte nodvendig, fordi det ikke altid giver sig selv, hvordan en videoproduktion skal opbygges for at ramme sin málgruppe.

Formidlingsanalysens mål $\mathrm{cr}$ at valge en fremstillingsform og en vinkling ved at give modtagerne en rakke konkrete informationer, som breder budskabet ud til de målgrupper, der er fremanalyseret i analysen af kommunikationssituationen. Man kan også i produktionsjargon sige, at det drejer sig orn at finde det vasentlige og se bort fra det uvasentlige, når man »ser « den gode tv-historie.

Formidlingsanalysen binder målgruppeanalyse og formidlingsastetik sammen gennem udvalgelse af den rigtige winkling. Man kan satse pă brede målgrupper, snæure målgrupper og indrette videoproduktionens komposition, stil og modalitet herefter, men det er forst og fremmest vinklingen (den overordnede fortallers synswinkel) og den afgrensning og det valg af informationer, der folger heraf, som er formidlingsanalysens krumtap. Det skal herudover ses i sammenhæng med, hvad man vil opnå med den kommunikation, man soger at skabe med det producerede video/indslag.

Eksempel: En videogruppe havde valgt at produm cere en 5 minutters produktion om den sadomasochistiske forening SMIL. Produktionen indleder med forskellige scener med pisk og lader (underlagningsmusik af Anne Linnet) efterfulgt af en rakke interviews med udovere og formanden for foreningen.

Af de informationer, som gives i indslaget gennem billeder og interview, fremgăr det, at sadomochistisme nok er anderledes og lidt til en side, men faktisk blot er en slags seksuelt krydderi oveni det mere normale. Og gruppen's målgruppe er da også meget bred (»danskere sådan $i$ almindelighed «).

Kommentar: Det formidlingsanalytiske problem er her, at man sager băde at ramme en bred mălgruppe af mormale« (ikke-sadomasochister) og »skabs-sadomasochister«, og derfor må relaterer sig til den seksuelle norm fremfor alle andre målestokke. Fremstillingen af det sadomasochistiske emne søger legitimation $i$, at det blot er lidt anderledes krydderi på hverdagen og ikke, at det reelt er en perversion, som afviger en del fra almindelig seksualitet. Meget fả i den sảkaldte normale mảlgruppe vil acceptere et budskab om, at vi allesammen i virkeligheden i mere eller mindre grad er sadomasochister, og derfor kan man ligeså godt tage skridtet fuldt ud og proklamere, at sadomasochisme er seksuelt anderledes, men at det er acceptabelt, og der findes en forening af ligestillede, hvor problemerne med at erkende, at man har anderledes seksuellc praferencer kan diskuteres. Forsøget pả at normalisere noget som er helt anderledes, er her udtryk for en mangelfuld formidlingsanalyse i sammenhang med manglende afgrænsning af målgruppen.

\section{Formidlingsaestetikken}

Formidlingsastetikken omfatter hele spektret af virkemidler, som det populart kaldes. Mere pracist beskrives virkemidleme af de fortalleteoretiske begreber (komposition, stil og modalitet), som benyttes til at opbygge et audiovisuelt forløb, efter at målgruppcanalyse $o g$ formidlingsanalyse er foretaget.

Det første trin - formidlingsanalysen - bestod i at formulere budskabet, meningen - den forste foreliggende kommunikationsintention - som et tema. Temaet er så at sige det teksiuelle udtryk for den oprindelige kommunikationsintention. Herefter stiller formidlingsastetikken sig til rädighed for produccnten mht. hvilke tekstuelle fremstillingsformer, dette tema kan fremfores i. Bàde fakta-genrerne og fiktionsgenrerne fremforer temaer, så samtidig med fastlaggelsen af temaet, er det 


\section{Model 2}

\section{anslag $\Rightarrow$ praesentation $\Rightarrow$ udvikling $\Rightarrow$ point of no return $\rightarrow$ klimaks $\rightarrow$ nedtoning}

nødvendigt at fastlegge stor-genren; er det fakta cller fiktion? I praksis er det valg som regel truffet, fordi man knytter sin formidling sammen med en institutionel sammenhang (f.eks. en slags nyhedsudsendelse, et magasinprogram osv.) - der er med til at forhåndsdefinere stor-genren.

Vælges fakta, stăr en bestemt række fortælleformer til rådighed, mens andre er bortvalgt. Vælges fiktion står andre til rådighed. Når disse valg er foretaget, kan analysen af videoens komposition, stil og modalitet fortsette. I de efterfolgende 3 eksempler har jeg valgt at se narmere pă kompositionen og herunder dramaturgien i produktioner produceret af studerende ved Institut for Film \& Medievidenskab og professionelle indslag fra $t v$-stationer. Senere følger eksempler på, hvorledes stil og modalitet indgår som analyseprocesser $\mathrm{i}$ av-metoden.

\section{Komposition}

Både i faktagenreme og i fiktionsgenreme er rakkefølgen af begivenheder/informationer af afgørende betydning for, hwordan modtageren konstruerer det audiovisuclle forløbs mening. I fiktionsgenrerne er standarddramaturgien og dens berettermodel en målestok for, hvordan man hensigtsmassigt opbygger en fiktionsfortalling.

Folger man rakkefølgen i model 2 , er man sikker på at fa fremstillet en forholdsvis enkel men ogsă logisk sammenhangende fortalling. I de tilfalde, hvor fortallingen ikke begribes af modtageren, skyldes det sjældent egentlige kompetence- eller præferenceforhold, men oftest fortællingskompositoriske fejl.

I fakta-genren benyttes også denne berettermodel, som mange indslag i ny hedsudsendelser er opbygget efter. Man finder dog ogsă mere klassiske former for fakta-formidling, f.eks. den tematisk styrede informationsrakkefølge, eller krydsklippede interviews mellem opponenter i en konkret sag/tema.

Eksempel: En videogruppe producerer et tiltankt nyhedsindslag til en af de storre nyhedsudsendelser. Det består i et sammenklippet interview med en dorvogter i et diskotek og en politiassistent. Det, de diskuterer, er i hvilket omfang dørvogterne må udfore egentlig politiarbejde, năr de smider halvberusede kunder ud af vagten og udforer afstraffelser (taisk) af lidt for aggressive kunder.

Politiassistenten siger lige ud, at de hverken har ressourcer eller lyst til at gribe ind i alle forlystelseslivets små skermydsler, og dorvogteren fortæeller os, at dorvogterne som en slags broderskab har en ikke skriftligt formuleret aftale med politiet om, at de sørger for lynjustits pả stedet og dermed aflaster etaten.

Kommentar: Rxkkefolgen (montagen) af dette fakta-indslags informationer fremstiller pointen i indslaget; at der findes en ikke uniformeret styrke af darmand som reelt udforer politiarbejde, de ikke har kompetence til, og at politiet velvidende herom ikke gor noget ved det. De to interviews ville imidlertid hver for sig ikke indeholde oplysninger, der i sig selv fremstiller indslagets mening. Politiassistentens mere generelle og abstrakte formuleringer uddbes og konkretiseres i dormandens meget beskrivende og konkrete oplysninger. Det afgorende er rakkefolgen af informationer, som komponeres igennem en krydsklipning af de to selvstandige og adskilte interviews.

Eksempel: En anden videogruppe skulle produm cere en reklamefilm for Kvicklys dybfrost, og konstruerer en fortalling om nogle tyve på spil i en Kvickly-butik om natten. Vi ser skumle personer (elefanthuer) undersøge varene i en Kvickly-butik. Udenfor standser en bil med hvinende bremser, en mand farer ud og ind i bygningen, peger på tyvene med en pistol $0 \mathrm{~g}$ råber »frys «, og det afsløres, at tyvene kun gik efter dybfrosne grontsager.

Kommentar: Selvom gruppen har arbejdet med en snydfortaller ${ }^{5}$, der holder viden tilbage om, hvad det egentlig er tyvene cr ude efter for til sidst. at afslore, at det er dybfrostvarer, er problemet i denne fortalling, at modtageren ikke făr de relevante men nodvendige informationer på et bestemt tidspunkt $\mathrm{i}$ fortallingen. Ingen ved nemlig, hvem manden, der ankommer i bilen er. Han er nemlig ikke blevet prasenteret, som tyvene er det: (elefanthuer på hovedet). I standarddramaturgien er presentationen en vigtig del af fortallingens infor- 
mation, som her mangler. Hvis man havde placeret et blåt blink på bilen, ville vi vide, at han tilho rer politikorpset, men hans uafklarede status giver wslark i fortæellingens logik. Modtageren ved heller ikke, om han er ansat i et vagtkorps eller lignende, og nogle troede (i den mini-receptionsanalyse der fulgte), at han var en af de andre tyve, som blot kom senere, indtil han holdt dem op med sin pistol.

Dramaturgien, som en redskabskasse eller et set af tommelfingerregler for, hvordan man bygger fiktionsfortallinger op, er nodvendig i planlagningen og konstruktionen af fortællingen. Dertil kommer også viden on de mange forskellige kompositionsformer, som ikke omfattes af standarddramaturgien-f.eks. snydfortalleren.

\section{Det historiske perspektiv}

Sxrligt når det drejer sig om kompositoriske forhold i fakta og fiktion er det historiske aspekt af den audiovisuelle metode relevant. Det er producentens filmhistoriske viden - selvom den med dette eksempel (Kvickly) ikke behøver at vare særlig pracis, som indgår i den kreative praproduktionsfase. Men det kan også være, at producenterne har gået mere akkurat til vaerks. Hvis de har gennemset et utal af reklamefilm indenfor de sidste 10 år eller, hvis de er gået længere tilbage i historien (f.cks. helt tilbage til begyndelsen af 50 'erne), så ville de se, at snydfortalleren er en yndet fortallekomposition i 30-50 sekunders reklamefilm og er brugt til at reklamere for mange forskellige produkter.

En tilsvarende historisk analyse kan foretages med alle praproduktionelle oplæg. En opgave om at producere et nyhedsindslag til en landsdakkende tv-kanal kan valge mellem feks. to historiske perspektiver; se hvorledes sådanne typiske indslag produceres i dag og analysere indslaget med den begrebsramme, der gives af den systematiske del af av-metoden - eller se pă hvorledes man de sidste 50 år (efter 2. verdenskrig) har produceret såvel tv-nyheder som newsreels, dokumentarfilm og derudover gå tvarmedialt til varks - hvordan arbejder den skrevne presse med nyhedsformidling? Ogsả i denne sammenhang skal den tidligere nyhedsformidling analyseres med de begreber, der stilles til rådighed af den systematiske del af av-metoden.

Denne vinkel på præproduktionen rejser dog et andet og meget vigtigt problem: Hvad udgor normerne for feks. nyhedsformidling - skal de cfter- kommes i ens eget produkt eller skal de overskrides? Og endelig - i hvilket omfang skal normerne andres?

Da TV 2 begyndte at udsende programmer i 1988, blev det $\mathrm{i}$ offentligheden debateret $\mathrm{i}$ hvilken grad, der var forskel påTV 2s nyheder og DRs nyheder. Senere undersøgelser bekrafter, at modtagerne opfatter DR som lidt gammeldags, men mereseriøs og TV 2 syhederne som mere frisk og ungdommelig. I offentligheden gik kritikken på de stilistiske forskelle eller mere pracist, som om det var stilistiske forskelle, men set i sammenhang med de her anvendte begreber, er det tydeligvis fâ men meget betydningsfulde kompositionsforskelle. I det efterfolgende skal et nyhedsindslag fra TV 2 analyseres.

Eksempel: Nyhederne indeholdte 11.3 .91 et indslag om fiksering og medicinering af psykisk afvigende fanger $i$ et af landets fangsler. Loven om tvangsmedicinering og fiksering af fanger skal tages op til revision af folketinget. En overlæge i psykiatri ved dette fengsel blev interviewet. Han sidder i venstre side af billedet, i brun-blomstret skjorte og har langt hår og briller. Han taler med intervieweren om, hvor krankende det er for den fikserede at blive tvunget til at opholde sig i en celle fastsprendt eventuelt tvangsmedicineret. Herefter interviewes den ledende fangselspsykiater om emnet. Hun er placeret i hojre side af billedet, grăhăret og $\mathrm{i}$ en lys troje. Hun taler for tvangsfiksering og medicinering som en nodvendighed i sarlige tilfalde, hvor ingen andre midler rakker. Ind imellem interviewene ses dakbilleder af fangselsmure, gitre, hegn og grasplæenen rundt om fangslet.

Kommentar: Modtageren er klar over det såvel verbale som visuelle modsatningsforhold mellem de to psykiaterc. Da intervieweren, der tillige er 3. personfortaller, under dakbillederne fortaller, at den forste psykiater er fritaget fra sit job, kan modtageren konstruere to sammenhangende meninger: at vi her har at gore med en oprorsk psykiater, der er imod the establishment og derfor (måske) af samme grund er fritaget fra sin tjeneste eller, at der blot er tale om en konkret uenighed to psykiatere i mellem, hvoraf den ene ik ke langere gor tjeneste samme sted som den anden (der er overordnet).

Den ene mening ser fritagelsen fra jobbet som en oplysning, der er mindre relevant for den samlede pointe, mens den anden mening munder ud i temaet; den enkelte kontra systemet, der yderligere fordobles i temaet tvang kontra frihed. Den sidste 
mening ligger tat op af andre indslag fra Nyhederne og skyldes her en specifik komposition af informationer, som igen relaterer sig til et brud på normerne for, hvordan sådanne oplysninger skal prasenteres. Oplysningen om den forste psykiaters fritagelse fra tjeneste er anbragt inde i forløbet, efter vi har faet prasenteret modsatningerne mellem de to psykiatere. Havde den varet anbragt $i$ begyndelsen af forlobet, havde det givet en helt anden mening - eller havde vi faet at vide, hvorfor han er fritaget fra tjeneste (hvad vi ikke ved det fjerneste om), ville det givetvis ogsă fore til en helt anden nyhed. Her bliver komposition af informationernes rækkefølge til en bestemt vinkling, der forer et bestemt tema med sig.

Sammenligner man med den konkurrerende kanal - DR - har den i en lang periode varet cksponent for en anden nyhedsopfattelse. I kraft af debatten i 70'erne om fairness, objektivitet og trovardighed havde DR i 80 'crnc (men ikke længere i 90 'erne) stadigvak et normsæt, som ikke tillod den type af nyhedskomposition, som ses i Nyhedernes om tvangsmedicinering og fiksering. De etablerede normer for faktafremstilling ville fă en sådan nyhed til alene at handle om de forskellige meninger og holdninger, der indgår i debatten forud for lovbehandlingen af forslaget i folketinget og ikke forskyde nyhedens offentlighedsvardi til en tematik omkring den enkelte kontra systemet. TV 2's Nyhederne er begyndt at narme sig dc klassiske idealer for faktaformidling, og DRs nyhedsformidling xndrer sig tilsvarende den modsatte vej, så de to kanalers nyhedsformidling mere og mere ligner hinanden.

Blandingen af fakta- og fiktionsfortalleformer er ogsă udtryk for forandringer i normerne for faktaformidling. Ingen er i tvivl om, at selvom små fortallinger iscenesattes som en blok midt i cn faktaramme, så vil hele indslaget stadig blive opfattet som fakta - modtageren vil stadig forankre indslaget i sin ovcrordnede institutionelle ramme, på trods af at de benyttede fortalletrak traditionclt tilhorer fiktionens.

Mere principielt bor de kreative av-producenter arbejde vertikalt - dvs. følge den systematiske procedure, hvor alle de formidlingsxstetiske, formidlingsanalytiske og kommunikationsteoretiske begreber involveres i den praproduktionelle fase og horisontalt, dvs. de samtidige og de på traditionen hvilende normer for formidling inddrages, năr der valges hvillke fortalletrak, man vil benytte sig af. At læegge sig i forlængelse af de normer (kon- ventioner), der galder for en bestemt undergenrer og udsendelsestype er fint nok. Det kræever dog stadigvak en god formidlingsanalyse, og i forlangelse heraf kan der produceres solide og sevæerdige programmer.

Onsker man at bryde de konventionelle rammer, overskride normerne for en given undergenre, kraves der en nøjagtig analyse af, hvilke dele af fortalleforholdene man onsker at bryde med. Producerer man et alternativt indslag til en $T V$-avis, hvor både stil, komposition og synsvinkler er æendret, ender det givetvis i en fremstilling, som kun de producerende selv forstår. Som hovedregel skal man kun æundre ét gennemgående fortalletrak - f.eks. stilen.

\section{Stil}

I fiktionsgenreme står et uendeligt sxt af muligheder til rådighed. Man kan lagge en særlige farvestil og tekstur i billederne; man kan klippe efter forskellige stilistiske systemer (f.eks. matchcut, montage, continuity og forskellige kombinationer af disse); man kan benytte kamerabevagelser, arbejde med objektfylde i kombination med klip og kamerabevagelser for at skabe bestemte harmoniske eller disharmoniske rytmer osv. I faktagenrerne er der - i kraft af normeme - meget begransede muligheder. Normen for faktaformidling er den neutrale stil, mens man i blandingsgenrerne f.cks. en faktaramme med et indskudt fiktionsindslag, kan markere fiktionsfortallingen med en sarlig farvestil eller tekstur. Det er forst og fremmest tv, som har udviklet disse normer. For filmens vedkommende cr f.eks. Cinema vérité-stilen en meget markeret form, med et evigt bevegeligt kamera og en grov tekstur som de mest typiske træk ${ }^{6}$.

En tilsvarende hverdagsagtig stil findes også i fiktionsserier (f.eks. Missing Persons (DR) 1994, Drabsufdelingen (TV 2) 1992 og NMPD (TV 2) 1995) og i ungdomsmagasinerne Zig Zag og Transit, hvor interviews og 1 . personfortalte indslag også fremfores i en stil, som minder om cinéma véritéstilen (et gyngende, zoomende og evigt bevegeligt kamera). Men hvor cinéma vérité-stilen er motiveret af optagelsesomstandighedernes realistiske forhold, er stilen i de to navnte ungdomsmagasiner langt mere umotiveret. Her er skave linjer, vilde zoom, køreture og kamerabevagelser mere lig den stil, som man finder i MTV.

Det er således en slags ungdomsstil, der satses pă, og stilens indbyggede modalitet henleder op- 
marksomheden pă, at programmet er produceret, $o g$ at der er tale om en slags manipuleret fjernsyn, som modtageren ser på. De to navnte ungdomsmagasiner er gode eksempler på, at man kan bryde med nogle normer for faktaformidling, hvis man bibeholder andre (selve indholdet er traditionelt. med undtagelse af visse "gale humoristiske indslag). Men der ogsă eksempler pă andre produktioner, hvor man ser et mere reflekteret opgor med normerne.

Eksempel: Et indslag til et ungdomsmagasin er produceret af en videogruppe. Det handler om politikeren Fleming Opfelt (V), om hans placering i folketinget på en af de bageste rakker, hans syn på magt og indflydelse og arbejdet som politiker i det hele taget. Alle indstillinger er foretaget i den săkaldte $»$ unge stil «, med et evigt bevagende kamera, fra forskellige vinkler og det hele klippet sammen i hojt tempo. På lydsiden er lagt et konstant gentagende lydsegment - et trommeslag efterfulgt af en ekko-lyd, der minder om en halvtosset latterytring. Når politikeren onsker en pause siger han: "Det klipper I vel ud «, hvorfor det selvfolgelig er medtaget. Imellem interview-segmenterne er indklippet filmcitater fra David Lynchs Vilde hjerter. Alt i alt leveres der et alternativt - måske let parodisk-portrat af en politiker.

Kommentar: Indslaget med Fleming Opfelt er er typisk eksempel på selv-refleksiv (modaliscrende) kommunikation, hvor både kompositionsforhold (at markere, at det er fremstillet for et publikum ved at pointere, at det er klippet, eller noget skal klippes ud, eller ved at vise selve optagelserne, lyssatningen og lydmanden), visuel stil - det evigt bevegende kamera og lydsidens kommentering gennem den specielt valgte musik fortæller om sit $\mathrm{cm}$ ne $o g$ forteller om sin egen fremstilling af emnet. Emnet $i$ sig selv er seriøst, men i fremstillingen af politikeren skabes gennem stilen en kraftig distance til den medieglade politiker og det medium, man selv producerer $\mathrm{i}$.

Stilistiske analyser er et vigtigt element i cnhver formidlingsproces, men oftest det, som forsømmes. Enten er det tilfaldigheder, der afgor farvestil og tekstur eller også tilstræbes en "normalæstetik «, det vil sige, en stil, der er så usynlig eller gennemsigtig, at modtagerens opmarksomhed kun henledes på indholdet. Men selv i faktaprogrammer pă tv bor man overveje stilistiske xendringer fra normen. For eksempel er programmet Opfinderliw (DR 1995) karakteriseret af en moderat ungdomsstil, mens den er mere rabiat i den voksne julckalender på samme kanal (Jule-X-Tra 1995). Og i helt overgearet form er stilen i DRs bilmagasin Kunsten at kobe en brugt bil (1996). I det hele taget sker der pt. store andringer i faktastilens normer - dog fortrinsvis i udsendelser udenfor de egentlige nyheder og beregnet for den unge målgruppe.

\section{Modalitet}

Modalitet betyder i denne sammenhang ${ }^{7}$, at en selvstændiggjort tekst (del af samlet tekst) - feks. lyden - "taler om « andre dele af teksten f.eks. billedsidens begivenheder. Det kan vare musikken, speaken eller effektlyde, som stiller sig i modsætning til billedsidens indhold eller blot lagger distance til det. Modalitetsbegrebet drekker alle former for tekstuel dobbeltkommunikation. Lige fra intertekstualitetens spil til parodier og satire (transtekstualitet), såvel som den interne modalitet (intratekstualitet), năr lydsidefortalleren går pă tvars af billedsidens fremstilling.

I faktagenreme er modaliteten som regel neutral; man kommenterer ikke fra 1.- eller 3. personfortallerens side de forskellige ytringer ironisk, parodisk eller satirisk og det ses aldrig, at lyd-billedsidemontagerne far et modaliserende prag (som f.eks. i ovennavnte indslag til et ungdomsmaga$\sin$, hvor lydsiden ironiserer eller parodierer billedsidens fortrellen - eller omvendt. Ligeledes ser man heller ikke i faktagenrerne stilen som en sarlig modaliserende faktor, som den feks, er i spillefilmen. En af de genrer, hvor modalitetsforhold bruges meget, er reklamefilmen og forskellige ungdomsserier. Arbejder man med praktisk produktion af reklamefilm og indslag til ungdomsserier er arbejdet med de forskellige former for modalitet af stor betydning.

Eksempel: Reklamefilmen for Carlsberg Light (TV 2) med Sonja og (dukken) Lillebror i hovedrollerne. Her er Lillebror sur over, at han ikke må fă lov at smage Sonjas Carlsberg Light. Han insisterer voldsomt, og til sidst bliver det for meget for Sonja, som klipper hans snore over, mens hun nyder et glas Carlsberg Light.

Kommeniar: Alle kender selvfolgelig den meget populare borneserie Ingrid og Lillebror fra 60'erne og 70 'erne. Her var den børneanarkistiske Lillem bror bade det forfriskende moment og igangsattende for Ingrids mildt opdragende kommentarer. Reklamefimens intertekstuelle distance er en modalitetsform, hvor den mnye « tekst kommenterer parodierer eller udleverer den »gamle tekst. I 
Carlsberg Light-reklamefilmen vendes humoren mod Lillebror. Den tidligere så overbxrende moderfigur (nu Sonja) forvandler sig til en straffende heks, der klipper Lillebrors »navlestrenge« over på grund af en ting: let øl!

Modalitet skaber distance, men forudsatter ide fleste tilfalde modtagerens kendskab til allerede eksisterende tekster for at få effekt. I ungdomsscrien Parker Lewis can't loose (TV 2, 1994-) benyttes interne tekstuelle virkemidler til at skabe distance mellem forskellige fortalletræk. Her er det især lydsiden, der bruges til at overdrive billedsidens begivenheder. Når en af de tre hovedpersoner f.eks. forelsker sig, og de to andre reagerer med vilde fagter, horer man på lydsiden deres gestik som sarlige swush-lyde, der netop legger distance til begivenhederne på billedsiden og dermed »kommenterer « dem. Det er iøvrigt et tekstuelt trak ved mange ungdomsastetiske udtryk, at de modaliserer, så de dermed undgår cntydige og alt for alvorlige budskaber.

Modalitetsformerne er mange og bor ogsả indgår i den systematiske procedure i praproduktionsfasen, enten som et klart valg eller som et klart fravalg, hvilket i forbindelse med mange faktaprom grammer er indlysende.

\section{Den systematiske og den historiske analyse}

I nogle tilfalde giver det sig selv, hvordan et tv-program skal bygges op og hvilke fortalleformer, der skal benyttes. Men i langt de fleste tilfalde skal der i proproduktionsfasen arbejdes ikke bare kreativt men også analytisk ved systematisk at gennemgå de faser i analysen, som beskrevet ovenfor. I alle led kan den historiske analyse af en genres udvikling af fortalleformer vare af stor nytte; det galder både, hvis man vil placere sit eget produkt indenfor genrenormerne eller, hvis man vil eksperimentere fra det overskridende til det vilde anarkistiske. Fortalletcorien udgør her et meget vigtigt sat af begreber, som muliggor en diskussion og forståclse af, hvorfor medierne ind i mellem faktisk făr den effekt, som de har. Det er derfor også af stor betydning for en afsender af et tekstuelt budskab i levende billeder, at pågaldende både foretager măl. gruppeanalyser, foretager en formidlingsanalyse og valger fortallenormer via en systematisk og en historisk analyse indenfor den mulige genre, som den kommende videoproduktion placerer sig $\mathrm{i}$.

\section{Sammenfatning}

Det sidste moment af kreativitet eller geniale indfald kan denne metode ikke tage livet af (og det skal den heller ikke). Den audiovisuelle metode er anvendelig $\mathrm{i}$ den proproduktionelle fase. Under produktion og postproduktionen kan den kun anvendes i meget begranset omfang.

Det, der er dens styrke, er, at den har operationaliscret teorierne, så de analytisk kan anvendes iformidlingsejemed. Ved at analysere kendte produktioner, de fortællemæssige forhold og de normer, der galder, er teorierne blevet brugt til at forstå den formidling, der har fundet sted under galdende betingelser. Dermed bliver idé-fasen og hele den forudgåcnde planlxgning frem til manus, drejebog og skydeliste indsat $i$ en film-og medieteoretisk og film- og tv-historisk ramme. Her kan man endvidere forestille sig analyser, der f.eks. fokuserer på en hel genres udvikling (f.eks. faktagenrens udvikling fra dokumentarfilm, newsreels til moderne tvnyheder), så man danner sig overblik over normudviklingen og ikke ensidigt fokuserer på, hvordan formidling fungerer her og nu. Den historiske-analytiske viden er også den minimale forudsatning for grenseoverskridende xendringer i băde form og indhold.

\section{Noter}

1. Her tankes pa alle mediem og fimteorier, der bem skaftiger sig med de levende billeders tesktuelle beskaffenhed, ceks. Bordwell 1985, Branigan 1984 , Kozloff 1988, Harms Larsen 1990, Hojbjerg 1986 o.a.

2. Argumentet imod ikke-institutionelt ancrkendtc teorier og disciphiner er, at de ikke er intersubjektivt: kontrollerbare, ureproducerbare osv. Imidlertid kan man med samme vagt argumentere imod megen humanistisk forskning. Hvor mange tekstanaly. ser underkastes egentig en intersubjektiv gyldighedsprocedure?

3. Det er en kendsgerning at mange tekstteorier blot er fremsat uden egentig at vare testet. Hvem har nogensinde verificeret de mange forskellige analysemodeller, der har foreret pä det akademiske marked? Mig bekendt er disse tekstmodeller (feks. Gromas forskellige tekstmodeller i Strukturel Seman(ik) aldrig blevet verificeret eller falsificeret. De er blot blevet anvendt med det skar af videnskabelighed de barer med sig i deres fremstillingsform. For ogsä indenfor teoriomrädet kan det diskuteres, om nogle teorier er egentlig videnskab (hard science) og reflekterer en teoretisk bearbejdning af empiriske data, eller blot er skrivebordsanalytiske konm 
struktioner, der halder mere til den astetske-tekstfortolkende tradition. Det kunne vere et ganske inm teressant projekt at fundersøgt, om det er en slags institutionspsykologisk grundlag, der ligger bag opm delingen i humanistisk videnskabelige discipliner pä den ene side og formidlingen pà den anden side?

4. De fortalleteore tiske begreber, der her anvendes, er: komposition (informationemes rakkefolgo og synsvinkler), stil og modalitet. Begrebenne er udviklet $i$ forlangelse af savel klassisk fortalleteori (Booth o.a.) som nyere (Bordwell, Branigan, Kozlof o. a.) af undertegnede i skrifteme" "Nyere fortalleteorier 1994 og Fondleteri 1: Audionisud formiding. 1996.

5. En swydfortaller er en salig organisering af begivenhedemes rekkefolge, der giver modtageren on wis viden, men begranset viden, for senere at afslore mere viden. Snydfortalleren bilder modtageren ind, at et bestemt handlingsforlob skal finde sted for derefter at afshute fortallingssegmentet med en overraskende pointe (feks i en reklamefilm, hvor man ser startlamper, en aslaltvej og horer en motorm brummen, hvorefter man ser en wbil (med subjektivt kamera) accelerere alt imens speaken forteller os, at wdet kan accelerere fra $0.100 \mathrm{~km}$ i timen pă under 8 sekunder, indtil det afslores, at det cr en reklame for en Zoologisk have (i USA), hvor man nu kan se verdens hurtigste dyr - en gepard!). Modtageren tror, at det er en bil, men ved samtidig at der er mere viden (overwaskende pointer) men ikke hvad. Han ender med at blive snydt.

6. Det galder kun film som: Primary 1960, The Chat 1962 og Corsis: Behwd a Presidential Cammitment 1963 der udmakker sig med den senere kanoniserede stil, mens resten af filmene fra samme skole a er ganske anonyme istilen.

7. Det modalitetsbegreb, der her bruges, stammer fra Bertel Pedersen 1976 og Robert Stam 1992.

\section{Litteratur}

Bordwell, David (1985) Namation in the Fiction Flm., Madison.
Branigan, Edward (1984) Point of Whew in the Cinema, Berw lin.

Breum, Trine (1993) Fortolling \& forforlse, Kobenhavn.

Burch, Nöel (1973) Theory of Film Pratice. London.

Franck. Knud og Gabold. Ingolf (1984) TV som udtrysmiddel, Personalekursus. DR.

Happé. Bernard L. (1975) Basic Mohion Picture Tednology, London.

Hojbjerg, Lennard(1986) $\gg$ De levende billeders udsigelse - fiktion og faktione Sekvens 1986.

Hojbjerg, Lennard (1988) »Forsog med en alternativ TV. avis Seluens 1988.

Hojbjerg, Lennard (1994) »Nyere fortalleteorier S kvens 1994.

Hojbjerg, Lennard (1996) Fortalleteri 1: Audiovisuel for midling, Kobenhavn.

Ingemann, Bruno (1979).... mere end wesivd ord: en bog om brug af billeder, Kobenhavn.

Ingemann, Bruno (1989) Buledteor, Roskilde Universitet.

Jensen, Klaus Bruhn (1994) „Nyheder til hverdag - Reception og brug afTV-nyheder in: Reception af levende billeder, red: Hojbjerg, Kobenhavn.

Kjorup, Soren (1994) "Semiotik og retorik Medie Kultur 22

Kozlof, Sarah (1988) Inwisible Stoptellew - Voice Over Nar ration in American Fiction Film, Berkeley.

Kuhn,Thomas S. (1962) The Structure of Scientific Revolutions, Chicago.

Jensen, Viggo Holm og Pryds, Henning (1987) Videotekni, forialleteknik, Kobenhavn.

Larsen, Peter (1974) "Analyse af TV-avisen (in: Medit sociologi, red: Poulsen og Andersen. Kobenhavn)

Larsen, Peter Harms (1990) Fakton som udryksmiddel. Dansklarerforeningen

Pedersen, Bertel (1972) Parodiens twor, Kobenhavn.

Prehn, Ole (1981) wTVavisen - en politisk underholdningsserie (in: Uhdeholdning i TV, red: Mortensen et al. Kobenhavn)

Stam, Robert (1992) Reflexivity in Film and Literature. From Don Quixote to Jean-Luc Godard, New York. 


\section{Anmeldelser}

Kultur \& Kommunikation

Samfundslitteratur, København, 1995

TV i kulturhistorisk perspektiv

Nordisk Kulturinstitut/Klim, Aarhus, 1994

Internationale TV-nyheder

Akademisk Forlag, København, 1995

Cognition, Emotion and Visual Fiction

Department of Film and Media Studies, Copenhagen, 1994

Paul Virilio - krigen, byen og det politiske

Rævens Sorte Bibliotek, København, 1994

Lydmediet i skolen

Danmarks Lærerhøjskole, København, 1995

The Dynasty Years

Routledge, London \& New York, 1995 